\title{
PARLAMENTAR PODE, SIM, PROPOR LEI EM MATÉRIA FINANCEIRA
}

Coluna publicada em 4.7.2013: <http://www.conjur.com.br/2013-jun-04/ contas-vista-parlamentar-sim-propor-lei-materia-financeira $>$

Escrevo a respeito de um tema sobre o qual já publiquei, ${ }^{1}$ mas que ainda me intriga e merece nova abordagem, desta vez em tom menos acadêmico, que permite atingir um público mais amplo, razão pela qual este espaço se mostra ideal.

Trata-se da iniciativa de leis em matéria financeira, assunto que, curiosamente, ainda se mostra desconhecido não somente pelo público, mas também pelos maiores interessados nele, que são os parlamentares de todo o país.

O processo legislativo, conjunto de atos por meio do qual são formadas as leis e demais normas que compõem nosso ordenamento jurídico, é basicamente composto de três fases. A iniciativa, por meio do qual o processo é deflagrado; a constitutiva, na qual se dá a tramitação e aprovação; e a fase de integração e eficácia que compreende a promulgação e publicação. Embora seja um processo, em tese, próprio do Poder Legislativo, ele conta com a participação dos demais poderes, especialmente do Executivo, que tem competência para a iniciativa em vários temas, cabendo-lhe ainda a sanção, na fase final de aprovação, além de muitas outras intervenções.

No âmbito das finanças públicas, a distribuição das atribuições em matéria de processo legislativo mostra-se mais sensível, dado o grande poder envolvido no

1 Iniciativa legislativa em matéria financeira. In: CONTI, José Mauricio; SCAFF, Fernando F. (coords.). Orçamentos públicos e direito financeiro. São Paulo: RT, 2011, p. 283-307. Tendo em vista que o tema já foi abordado nesta publicação, argumentos desenvolvidos e trechos escritos serão por vezes reproduzidos, ainda que não com a exata redação, dado o outro estilo de linguagem adotado, razão pela qual me permito não colocar aspas. E remeto o leitor ao texto original já publicado, caso tenha interesse em se aprofundar no tema. 
controle sobre os recursos públicos. Torna-se necessário construir um cuidadoso sistema que permita a participação dos poderes nesse processo de forma a evitar que uma desigual distribuição venha a permitir que um se sobreponha ao outro.

Sendo o Poder Executivo o principal responsável pela condução da administração pública, a ele cabem importantes atribuições no processo legislativo orçamentário, destacando-se a iniciativa privativa (ou reservada) e vinculada dos projetos de leis orçamentárias anuais, de diretrizes orçamentárias e planos plurianuais (art. 165 da Constituição). Trata-se de competência que lhe confere um grande poder, sendo, no entanto, coerente e necessária, até porque o Poder Executivo detém o comando da maior parte da administração pública, compreendendo os órgãos responsáveis pela arrecadação de recursos e de coordenação do processo de elaboração e execução orçamentárias.

Mas há um aspecto extremamente curioso e que chama a atenção. Trata-se de fato sobejamente conhecido, sendo verdadeiramente "público e notório", que são de iniciativa legislativa os projetos de lei em matéria financeira em geral, tais como os que envolvam gasto público, leis tributárias e outras questões orçamentárias. Iniciativa privativa esta que, em sendo aplicada - como de fato tem sido - aniquila quase toda a possibilidade de o Poder Legislativo iniciar o processo legislativo, pois passam a ser raros os casos de projetos de lei que tenham relevância e não envolvam as questôes mencionadas. Como bem definiu recentemente o presidente da Câmara de Vereadores de São Paulo, vereador José Américo (PT), fica o Poder Legislativo "de mãos atadas".

O vereador queixa-se da impossibilidade de legislar sobre política tributária e de elaborar projetos que gerem despesas, sugerindo que se reflita sobre isso ("A ideia de que os Legislativos não podem elaborar projetos que gerem custos extras precisa ser revista”, diz ele), expressando o pensamento de quase todos os parlamentares do País, de todas as esferas de governo, e pede apoio em favor de emenda constitucional que restaure as prerrogativas do Poder Legislativo.

A norma, no entanto, não precisa ser revista. E não precisa pelo simples fato de que tal vedação simplesmente não existe. Mas a "ideia" precisa.

Curioso por saber a origem dessa "vedação", descobri-a consultando a Constituição anterior, na qual constava, em seu artigo 57, I, que "é da competência exclusiva do presidente da República a iniciativa das leis que disponham sobre matéria financeira" (Constituição brasileira de 1967, com redação da Emenda Constitucional

2 José Américo Dias. Um Legislativo de mãos atadas. Folha de S.Paulo, em 2 de maio de 2013, p. A6. 
1, de 1969; a Constituição de 1967, texto original, tinha a mesma redação, alterando-se o artigo, que era de número 60, I). Ocorre que tal dispositivo desapareceu na Constituição de 1988, não havendo, por conseguinte, por que prevalecer esta iniciativa privativa das leis que disponham sobre matéria financeira. Trata-se de norma que deixou de constar de nossos textos legais, mas que parece se recusar a sair do ordenamento jurídico, pois continua sendo cumprida, como se pode notar.

Construção jurisprudencial, poder-se-ia cogitar. Também não. Submetida a questão à nossa Suprema Corte, pouco após a promulgação da Constituição Federal de 1988, o ministro Celso de Mello bem observou que "a Constituição Federal de 1988 não reproduziu em seu texto a norma contida no artigo 57, I, da Carta Política de 1969, que atribuía ao Chefe do Poder Executivo da União a iniciativa de leis referentes a matéria financeira, o que impede, agora, vigente um novo ordenamento constitucional, a útil invocação da jurisprudência que se formou, anteriormente, no Supremo Tribunal Federal, no sentido de que tal constituía princípio de observância necessária, e de compulsória aplicação, pelas unidades federadas" (ADI-MC 352, relator ministro Celso de Mello, julgado em 28 de agosto de 1990). E completa e ratifica, pouco depois, em outro julgado, ao asseverar que a regra da iniciativa reservada é exceção, sendo aplicável somente se prevista expressamente no texto, não se presumindo nem comportando interpretação ampliativa (ADI 724-6/RS, relator ministro Celso de Mello, julgado em 7 de maio de 1992).

A suposta restrição à iniciativa legislativa em matéria financeira não está nem na lei, nem na jurisprudência.

E também na doutrina não encontra respaldo, pois, além do texto que escrevi, outros autores já haviam anteriormente sustentado essa mesma tese. ${ }^{3}$

E não há que se falar em eventual disposição legal expressa nesse sentido nos demais entes da federação estabelecendo a vedação para a iniciativa do Poder Legislativo nessa matéria, pois "as regras básicas do processo legislativo federal são de absorção compulsória pelos Estados-membros em tudo aquilo que diga respeito como ocorre às que enumeram casos de iniciativa legislativa reservada - ao princípio fundamental da independência e harmonia dos poderes, como delineado na Constituição da República" (ADI 276-7/AL, relator ministro Sepúlveda Pertence, julgado em 13 de janeiro de 1997). ${ }^{4}$

3 FERRARI Filho, Sérgio A. Plebiscito, matéria orçamentária e iniciativa privativa. Parecer 14/1999 - SAFF. Revista Direito, vol. 4, n. 7, Rio de Janeiro, jan.-jun. 2000, p. 247-267.

4 No mesmo sentido: ADI 2.731-0/ES, j. 20.3.2003 e ADI 2.892-8/ES, j. 19.2.2004, ambos de relatoria do Min. Carlos Velloso. 
Ouve-se dizer que, na administração pública, vigora o não escrito e não jurídico princípio do "sempre foi assim", e talvez seja essa a explicação mais plausível para esse fenômeno, em que essa "norma" permanece plenamente eficaz, apesar de não mais existir!

Para um país em que muitos se queixam das "leis que não pegam", fica o registro, ainda que eventual, dessa "lei" que "pegou" até demais, pois continua sendo cumprida mesmo depois de excluída do texto da Constituição...

Não pode ser outra a conclusão: nossos parlamentares têm iniciativa para propor leis que disponham sobre matéria orçamentária (salvo, evidentemente, as leis orçamentárias - PPA, LDO e LOA), tributária e mesmo as que envolvam aumento de despesa pública. ${ }^{5}$

E finalizo, com licença do presidente Barack Obama para adaptar seu slogan de campanha, mandando meu recado aos parlamentares de todo o país: yes, you can!

5 Ressalvadas aquelas em que há disposições constitucionais expressas, tais como a criação de cargos e remuneração de servidores. 